特 集

\title{
『磁気機能性流体・材料の歴史と展望（1)』の特集にあたつて
}

\section{Special Issue on History and Future Trend of Magnetic Functional Fluids and Materials (1)}

\author{
岩本 悠宏 ${ }^{* 1}$ (正員)
}

Yuhiro IWAMOTO (Mem.)

磁気機能性流体, 特に本特集で扱う磁性微粒子分散 系機能性流体は，外部から磁場を印加することで，そ の熱物性, 機械的性質, 磁気特性や動的な挙動等を制 御することが可能である。このような磁性微粒子分散 系の機能性流体は, その粒子サイズや混合方法により, 磁性流体 (Magnetic Fluid: MF), 磁気粘性流体 ( Magnetorheological Fluid: MRF), 磁気混合流体 (Magnetic Compound Fluid: MCF), 反磁気粘性流体 (Inverse Magnetorheological Fluid: IMRF) に分類される。 上記磁気機能性流体の歴史は古く, 20 世紀前半に流体 が開発され，その理論体系の構築，基礎・応用研究開 発が工学のみならず医療や芸術も含んだ，非常に広い 分野で展開されている。この発展には, 磁気機能性流 体が誕生した当初から日本の貢献は非常に大きい。

本特集では，「磁気機能性流体・材料の歴史と展望」 と題し, Vol. 29 の No. 3 と No. 4 の 2 号にわたって, 特集を企画した。No.3 では, 特に磁気機能性流体の発 展に多大に貢献された以下の方々に, 磁気機能性流体 の歴史と展望について, 執筆をお願いした。なお, No. 4 では, 最新の磁気機能性流体・材料の研究開発とそ の動向について，執筆を依頼している。

(1) 磁性流体の歴史と今後, 山口博司（同志社大学）

(2) MR 流体および関連研究について, 澤田達男

(Kasetsart University)

(3) 磁気混合流体の歴史と今後, 西田均（富山高等専 門学校)

(4) 次世代磁性流体用磁性酸化鉄ナノ粒子開発の現 状と展望, バラチャンドラン ジャヤデワン（滋賀 県立大学）他

(敬称略)

連絡先：岩本 悠宏, $\bar{\top} 466-8555$ 愛知県名古屋市昭和区御 器所町, 名古屋工業大学電気・機械工学科機械工学分野 e-mail: iwamoto.yuhiro@nitech.ac.jp

${ }^{* 1}$ 名古屋工業大学
まず，(1)「磁性流体の歴史と今後」では，磁性流体 の世界史，日本史についての概説とともに，磁性流体 力学の発展と合わせて, 諸物理を応用した研究開発に ついて紹介頂いた。

次に, (2)「MR 流体および関連研究について」では, 長年の MR 流体に関する研究の経験を基に, MR 流体 研究の小史の概説とともに，MR 流体と磁性流体の歴 史的な関わりについて紹介頂いた。

また, (3)「磁気混合流体の歴史と今後」では, 磁気 混合流体の誕生の歴史とともに, 磁気混合流体の特徵, 特に磁性流体や MR 流体との違い, また磁気混合流体 を用いた研磨技術について詳細に紹介頂いた。

続いて, (4)「次世代磁性流体用磁性酸化鉄ナノ粒子 開発の現状と展望」では，磁性流体に用いられる磁性 微粒子の合成，さらにはそれを磁性流体化する際の課 題に触れ，ナノサイズの磁性微粒子の磁気物性やその 流動特性，さらには次世代の磁性流体開発に向けて考 えられる課題と指針について，詳細に紹介頂いた。

本特集では, 磁性流体, 磁気粘性流体, 磁気混合流 体の歴史と展望，さらには磁性微粒子合成による今後 の磁気機能性流体の発展と指針について，それぞれの 分野を代表する著名な研究者に紹介頂いた。本特集を 企画するにあたり, $\mathrm{nm}$ サイズの粒子が分散する磁性 流体， $\mu \mathrm{m}$ サイズの粒子が分散する磁気粘性流体につ いて，長年これらの研究が独立していたように思われ る。一方で, 本特集は, これらの垣根を超え, 磁性微 粒子分散系の機能性流体として, 包括的にその歴史と 展望が詳述されている点で，これまで類を見ない構成 となっている。本特集が，学術のみならず産業分野の 発展の一助となり, 新しい研究開発の種となれば深甚 である。 